Short Communication

\title{
Vitamin content of four marine microalgae. Potential use as source of vitamins in nutrition
}

\author{
Jaime Fabregas, Concepcion Herrero \\ Departamento de Microbiologia, Facultad de Farmacia, Universidad de Santiago, \\ Santiago de Compostela, Spain
}

Journal of Industrial Microbiology, June 1990, Volume 5, Issue 4, pp 259-263

\section{How to cite}

Fabregas, J. and C. Herrero. 1990. Vitamin content of four marine microalgae.

Potential use as source of vitamins in nutrition. Journal of Industrial Microbiology 5(4): 259-263

The final publication is available at Springer via http://dx.doi.org/10.1007/bf01569683

\section{SUMMARY}

Certain marine microalgae contain water-and lipid-soluble vitamins and can be used as food supplements or food ingredients. A number of vitamins are present in higher concentrations in the microalgae than in conventional foods traditionally considered rich in them. Ingestion of relatively small quantities of microalgae can cover the requirements for some vitamins in animal nutrition, including human nutrition, while supplementing others. Marine microalgae can thus be considered to represent a non-conventional source of vitamins or a vitamin supplement for animal or human nutrition. 


\section{Keywords}

Marine microalgae; Vitamins; Nutritional requirements; Vitamin supplements

\section{INTRODUCTION}

Marine microalgae are considered today to be an important potential for a variety of products: they are useful in aquaculture [20,28], in the bioconversion of solar energy [17, 18], as a source of glycerol, carotene and dry algal meal [5], pharmaceutical products [1, 9], a raw material for Single Cell Protein (SCP) [10], or as supply of minerals in fish diets [11]. We report here the vitamin composition of four marine microalgae and consider their potential use as source of vitamins for animal and/or human nutrition.

\section{MATERIALS AND METHODS}

Raw material. Four marine photosynthetic microalgae were selected for this study: Tetraselmis suecica (Prasinophyceae), Isochrysis galbana (Haptophyceae), Dunaliella tertiolecta and Chlorella stigmatophora (Chlorophyceae). Culture conditions for these micro algae had previously been optimized for maximum biomass production [12-15]. Tetraselmis suecica was isolated from Ria de Arosa waters (NW of Spain); the remaining species were obtained from The Culture Centre of Algae and Protozoa, in Cambridge, U.K.

Analytical methods. The cells were collected at the end of their logarithmic phase, centrifuged at $3000 \times \mathrm{g}$ and dryed in an oven at $60^{\circ} \mathrm{C}$ for $24-30 \mathrm{~h}$. Samples for $\beta$ carotene determination were saponified under reflux and extracted with hexane. An aliquot of the hexane extract was chromatographed on alumina and the $\beta$-carotene determined by a colorimetric method [7]. Results were expressed as vitamin A activity in I.U., taking into account that 1 I.U. of vitamin $A=0.6 \mu g$ of $\beta$-carotene. Group B vitamins and biotin were determined by microbiological assays [2,27]. The microorganisms used for these determinations were Lactobacillus fermenti (ATCC 9338) for thiamin, Lactobacillus casei (ATCC 7469) for riboflavin and folic acid assays, Lactobacillus leichmanii (ATCC 7830) for cobalamin, Lactobacillus arabinosus 
(ATCC 8041) for nicotinic acid, pantothenic acid and biotin, and Saccharomyces carlsbergensis (ATCC 9080) for pyridoxin. Each vitamin was assayed, after the corresponding extraction procedure [2,27], in the vitamin assay medium of Merck. Vitamin E was extracted with petroleum ether and diethyl ether [19], the extract chromatographed by Florisil (SIGMA) and the vitamin E determined fluorimetrically in the appropriate fraction [6]. Ascorbic acid was determined as described by Roe [26] and Omaye [22].

\section{RESULTS AND DISCUSSION}

The vitamin composition pattern was very similar in the four marine microalgae assayed (Table 1). In general, they are rich in lipid-soluble and B group vitamins. The microalgae showing maximum concentrations of the different vitamins were Tetraselmis suecica for thiamin, pyridoxin, nicotinic acid, pantothenic acid and ascorbic acid; Dunaliella tertiolecta for $\beta$-carotene, riboflavin, cobalamin and folic acid, and Chlorella stigmatophora for tocopherol (vitamin E) and biotin (Table 1). In addition, almost all the remaining vitamins were found in high concentrations and all the vitamins assayed were found in the four marine micro algae studied. Four vitamins, $\beta$-carotene, tocopherol, thiamin and folic acid, were found in higher concentrations in some of these marine microalgae than in conventional foods traditionally considered as rich sources of these vitamins (Table 2). The microalgae showing these maximum concentrations were D. tertiolecta and C. stigmatophora for vitamin A activity, and T. suecica and D. tertiolecta for thiamin. All the microalgae assayed presented higher tocopherol and folic acid values than the conventional foods reported. Tocopherol values are especially high in T. suecica and C. stigmatophora, with 421.8 and $669.0 \mathrm{mg} / \mathrm{kg}$ (dry weight), respectively, whereas the highest folic acid value occurred in $D$. tertiolecta $(4.8 \mathrm{mg} / \mathrm{kg}$ dry weight). 
Vitamin content of four marine microalgae

\begin{tabular}{|c|c|c|c|c|}
\hline & T. suecica & I. galbana & D. tertiolecta & C. stigmatophora \\
\hline Vitamin A & 493750 & 127500 & 137500 & 82300 \\
\hline Tocopherol (E) & 421.8 & 58.2 & 116.3 & 669.0 \\
\hline Thiamin $\left(\mathrm{B}_{1}\right)$ & 32.3 & 14.0 & 29.0 & 14.6 \\
\hline Riboflavin $\left(\mathrm{B}_{2}\right)$ & 19.1 & 30.0 & 31.2 & 19.6 \\
\hline Pyridoxin $\left(\mathrm{B}_{6}\right)$ & 2.8 & 1.8 & 2.2 & 1.9 \\
\hline Cobalamin $\left(B_{12}\right)$ & 0.5 & 0.6 & 0.7 & 0.6 \\
\hline Folic acid & 3.0 & 3.0 & 4.8 & 3.1 \\
\hline Nicotinic acid & 89.3 & 77.7 & 79.3 & 82.5 \\
\hline Pantothenic acid & 37.7 & 9.1 & 13.2 & 21.4 \\
\hline Biotin $(\mathrm{H})$ & 0.8 & 1.0 & 0.9 & 1.1 \\
\hline Ascorbic acid (C) & 191.0 & 119.0 & 163.2 & 100.2 \\
\hline
\end{tabular}

Vitamin A content is expressed as IU $/ \mathrm{kg}$ dry weight $(1 \mathrm{IU}=0.6 \mu \mathrm{g}$ of $\beta$-carotene). The other vitamins are expressed as $\mathrm{mg} / \mathrm{kg}$ dry weight

There is a considerable variation in the concentration of certain vitamins, such as $\beta$-carotene, tocopherol, pantothenic acid or thiamin, among the different species assayed, whereas the concentration of other vitamins appears similar. This characteristic could allow us to chose different mixtures of marine microalgae in order to cover specific dietary requirements, taking into account certain constraints, such as the different vitamin concentration in the different species; besides, some micro algae are easier to culture than others.

Table 2

Vitamin contents of conventional foods which present maximum values for some vitamins [8]

\begin{tabular}{|c|c|c|c|c|c|c|c|}
\hline & Orange & Carrot & $\begin{array}{l}\text { Wheat } \\
\text { flour }\end{array}$ & $\begin{array}{l}\text { Corn } \\
\text { flour }\end{array}$ & $\begin{array}{l}\text { Rye } \\
\text { flour }\end{array}$ & $\begin{array}{l}\text { Soy } \\
\text { flour }\end{array}$ & $\begin{array}{l}\text { Cow } \\
\text { liver }\end{array}$ \\
\hline Vitamin $A^{*}$ & 14728 & $\begin{array}{l}175438- \\
1052631\end{array}$ & 0 & 0 & 0 & 1538 & 659793 \\
\hline Tocopherol ${ }^{\mathrm{b}}$ & 17.82 & 39.47 & 25.00 & 0 & 9.41 & - & 34.36 \\
\hline Thiamin $^{\mathrm{b}}$ & 6.20 & 11.40 & .6 .36 & 4.31 & 5.34 & 8.46 & 9.27 \\
\hline Riboflavin ${ }^{\mathrm{b}}$ & 2.32 & 5.26 & 1.36 & 1.25 & 2.38 & 3.07 & 96.21 \\
\hline Pyridoxin ${ }^{b}$ & 9.30 & 16.66 & 4.54 & 11.36 & 4.11 & 6.12 & 34.36 \\
\hline Cobalamin $^{\mathrm{b}}$ & 0 & 0 & 0 & 0 & 0 & 0 & 1.03 \\
\hline Folic acid ${ }^{b}$ & 2.66 & 1.48 & 0.66 & - & 0.9 & - & 1.71 \\
\hline Nicotinic acid ${ }^{b}$ & 15.50 & 56.14 & $11-45$ & 22.72 & 19.31 & 3.29 & 553.26 \\
\hline Pantothenic acid ${ }^{b}$ & 15.50 & 70.17 & 22.72 & 0.56 & 11.76 & 19.35 & 171.82 \\
\hline Biotin $^{b}$ & 0.07 & 0.06 & 0.08 & - & 0.007 & - & 6.87 \\
\hline Ascorbic acid ${ }^{b}$ & 3798 & 377 & 0 & 0 & 0 & 0 & 1065 \\
\hline
\end{tabular}

${ }^{a}$ I.U./kg dry weight.

${ }^{\mathrm{b}} \mathrm{mg} / \mathrm{kg}$ dry weight.

It is difficult to compare the data obtained with those of other micro algae because there are very little reports on the vitamin content of microalgae and the contents of vitamins found in pure cultures of algae varied and were dependent upon the vitamin level in the external medium [25]. Data reported are normally referred to freshwater microalgae and show great differences, even for the same species [3, 4, 23]. 
The marine microalgae selected for this investigation have been reported to represent a good raw material for the production of Single Cell Protein (SCP): the organisms have an excellent biological value, high protein level, aminoacid profiles comparable to the FAO reference protein and a nucleic acid content of less than $7 \%$ of dry matter [10]. Their potential use should therefore not be considered only as a protein source but also as a vitaminrich food ingredient or supplement.

Dunaliella tertiolecta presented the best pattern having the highest protein (54.25\% dry weight) and the lowest nucleic acid (4.83\%) content [10]. The best vitamin profile is also found in this organism, containing maximum values of four of the vitamin assayed and containing these four vitamins ( $\beta$-carotene, tocopherol, thiamin and folic acid) in higher concentrations than conventional foods. Its importance as a food supplement is highlighted by recent medical studies that have pointed out that human cancer risks are inversely correlated with dietary $\beta$-carotene intake [24]. The overall compositional profile of this microalga suggests its use as a health food. This is enhanced by the fact that D. tertiolecta lacks cell wall [21], showing better digestibility than cell wall possessing species. In the same way, hypocholesterolemic properties of D. tertiolecta have also been reported recently [16]. The intake of $3.63 \mathrm{~g}$ of $D$. tertiolecta per day can cover the human requirements for vitamin A; $7.14 \mathrm{~g} / \mathrm{day}$ covers the cobalamin and vitamin A requirements and serves as a supplement for the other vitamins, although a large intake would be needed to cover the requirements of some vitamins such as pyridoxin, nicotinic acid and ascorbic acid. However, it must be taken into account that this microalga would not be used as sole food in the animal or human diet, but as a component or ingredient that can supply vitamins, besides protein [10] and minerals [11].

These characteristics suggest a potential use of these marine micro algae as health foods or as dietary supplements.

\section{ACKNOWLEDGEMENTS}

This work was supported by a grant from Comision Asesora de Investigacion Cientifica y Tecnica (CAICYT), Madrid, Spain (n AC86-0006). Thanks to Prof. Ernest R. Pariser (M.I.T., U.S.A.) for his interesting comments. 


\section{REFERENCES}

1. Aaronson S., T. Berner and Z. Dubinsky. 1980. Microalgae as source of chemicals and natural products. In: Algae Biomass. Production and Use (Shelef, G. and C.J. Soeder, eds.), pp. 575-602, Elsevier/North Holland Biomedical Press, Amsterdam.

2. The Association of Vitamin Chemists. 1966. Methods of Vitamin Assay. Inc. 3rd Ed. Interscience Publishers. New York, London, Sydney.

3. Becker, E.W. 1986. Nutritional properties of microalgae: potentials and constraints. In: Handbook of Microalgal Mass Culture (Richmond, A., ed.), pp. 339-419, CRC Press, Boca Raton, Florida.

4. Becker, E.W. and L.V. Venkataraman. 1982. Biotechnology and Exploitation of Algae. The Indian Approach. Deutsche Gesellschaft für Technische Zusammenarbeit GmbH. Eschborn, F.R.G., 216 pp.

5. Ben-Amotz A. and M. Avron. 1980. Glycerol, $\beta$-carotene and dry algal production by commercial cultivation of Dunaliella. In: Algae Biomass. Production and Use (Shelef G. and C.J. Soeder, eds.), pp. 603-610, Elsevier/North Holland Biomedical Press, Amsterdam.

6. Demetriou, J.A. 1969. Determination of vitamin E. In: Clinical Chemistry, Principles and Technics (Henry, R.J. and J.W. Winkelman, eds.), pp. 1415-1417, Editorial Jims, Barcelona (Spanish edition).

7. De Ritter, E. and A.E. Purcell, 1981. Carotenoid analytical methods. In: Carotenoids as Colorants and Vitamin A Precursors (Bauernfeind, J.C., ed.), pp. 815-882. Academic Press, New York.

8. Documenta Geigy. 1975. J.R. Geigy, Basle, Switzerland.

9. Dubinsky, Z. and S. Aaronson. 1982. Review of the potential uses of microalgae. In: Biosaline Research (San Pietro, A., ed.), pp. 181-206, Plenum Press, New York.

10. Fabregas, J. and C. Herrero. 1985. Marine microalgae as a potential source of single cell protein (SCP). Appl. Microbiol. Biotechnol 23: 110-113.

11. Fabregas, J. and C. Herrero. 1986. Marine microalgae as a potential source of minerals in fish diets. Aquaculture 51: 237-243.

12. Fabregas, J., C. Herrero, J. Abalde and B. Cabezas. 1986. The marine microalga Chlorella stigmatophora as a potential source of single cell protein: enhancement of the protein content in response to nutrient enrichment. J. Ind. Microbiol. 1: 251-257.

13. Fabregas, J., C. Herrero, B. Abalde, R. Liaño and B. Cabezas. 1986. Biomass production and biochemical variability of the marine microalga Dunaliella tertiolecta (Butcher) with high nutrient concentrations. Aquaculture 53: 187-199. 
14. Fabregas, J., C. Herrero, B. Cabezas and J. Abalde. 1985. Mass culture and biochemical variability of the marine microalgaTetraselmis suecica (Kylin) Butch with high nutrient concentrations. Aquaculture 49: 231-244.

15. Fabregas, J., C. Herrero, B. Cabezas and J. Abalde. 1986. Biomass production and biochemical composition in mass cultures of the marine microalga Isochrysis galbana Parke at varying nutrient concentrations. Aquaculture 53: 101-113.

16. Fabregas, J., C. Herrero, M. Parafita, J.M. Paz, B. Cabezas and J. Abalde. 1988. Decrease in plasma cholesterol, triglycerides and CPK levels in rats fed on the marine microalgaDunaliella tertiolecta. Planta Medica 2: 109-111.

17. Goldman, J.C. 1979. Outdoor algal mass culture. I. Applications. Water Res. 13: 1-9.

18. Kharatyan, S.G. 1978. Microbes as food for humans. Ann. Rev. Microbiol. 32: 301327.

19. Laidman, D.L., J.K. Gaunt, G.S. Hall and C.T. Broad. 1971. Extractionoof tocopherols from plant tissues. In: Methods of Enzymology, Vol XVIII (McCormick, D.B. and L.D. Wright, eds.), pp. 366-369, Academic Press, New York.

20. McVey, J.P. (ed.), 1983. CRC Handbook of Mariculture. Vol. I. Crustacean Aquaculture. CRC Press Inc. Florida, 441 pp.

21. Oliveira, L., T. Bisalputra and N.J. Antia. 1980. Ultrastructural observation of the surface coat of Dunaliella tertiolecta from staining with cationic dyes and enzyme treatment. New Phytol. 85: 385-392.

22. Omaye, S.T., J.D. Turnbull and H.E. Sauberlich. 1979. In: Methods in Enzymology, Vol. 62 (McCormick D.B. and L.D. Wright, eds.), pp. 3-11, Academic Press, New York.

23. Payer, H.D., W. Pabst and K.H. Runkel. 1980. Review of the nutritional and toxicological properties of the green alga Scenedemus obliquus as a single cell protein. In: Algae Biomass. Production and Use (Shelef, G. and C.J. Soeder, eds.), pp. 787-797, Elsevier/North Holland Biomedical Press. Amsterdam.

24. Peto, R., R. Doll, J.D. Buckley and M.B. Sporn. 1981. Nature 290: 201-208.

25. Provasoli, L. and A.F. Carlucci. 1974. Vitamins and growth regulators. In: Algal Physiology and Biochemistry (Stewart, W.P.D., ed.), pp. 741-777, Blackwell Scientific Publications.

26. Roe, J.H. 1966. In: Methods of Biochemical Analysis, Vol. I (Glick, D., ed.), pp. 115139, Interscience Publishers.

27. Strohecker, R. and H.M. Henning. 1963. Vitamin Bestimmungen. E. Merck, Darmstadt, Verlag Chemie GmbH, Weinheim/Bergstrasse.

28. Walne, P.R. 1974. Culture of Bivalve Molluscs. 50 Years' Experience at Conwy. 173 pp. Fishing New (Books), Furhan. 